\title{
KAJIAN ETHYLENE TRIPLE RESPONSE TERHADAP KECAMBAH BEBERAPA VARIETAS KACANG BUNCIS (Phaseolus vulgaris L.)
}

\author{
Rivaldo Wellyem Sahilatua ${ }^{1)}$, Feky Recky Mantiri ${ }^{1)}$, Marhaenus Johanis Rumondor ${ }^{1)}$ \\ ${ }^{1)}$ Program Studi Biologi FMIPA UNSRAT Manado, 95115
}

\begin{abstract}
One of the appropriate cultivation techniques to increase land productivity, is intercropping cultivation. Intercropping is causing the plant to grow in shelter. This sheltered situation can increase ethylene production, giving rise to a triple response (inhibits stem lengthening, thickening of the stem, and the appearance of the habit of making hooks that cause the stem to grow horizontally or horizontally) that could affect plant growth and development. The aim of this study was to look for varieties of snaps (Phaseolus vulgaris) that were less sensitive to the increasing of ethylene which was reflected in the form of a minimal response to high ethylene levels. The research method used was Test Paper Rolled and Placed in a Standing Position with Plastic. Three varieties used were Horti I, Horti II, and Lokal variet were germinated with treatment (carbide administered) and had been control for five days. The difference data between the measurements of controls minus the treatment, then analyzed with one way ANAVA followed by using the 5\% LSD method (Smallest Significant Difference). The results were obtained for the higher hypocotyl length of Horti I variety $(1,07 \mathrm{~cm})$, the largest hypocotyl diameter of Horti II variety $(0,13 \mathrm{~cm})$, the largest epicotile bend of Horti II variety $(7,22 \mathrm{~cm})$, the largest epidermis cell length of Local variety $(12,17$ $\mu \mathrm{m})$, and epidermal cell width of Horti II variety $(5.06 \mu \mathrm{m})$. Based on the parameters obtained, Horti I varieties we less sensitive to increasing ethylene content therefore it can be concluded that variet Horti I could grow optimally in shelter condition.
\end{abstract}

Key words: Triple response, ethylene, shade, chickpea, carbide, hypocotyl, epicotyl, and epidermal

\begin{abstract}
ABSTRAK
Masalah yang umumnya dihadapi dalam membudidayakan tanaman buncis ialah kurangnya lahan untuk bercocok tanam. Teknik budidaya yang tepat untuk meningkatkan produktivitas lahan, salah satunya budidaya dengan pola tumpang sari. Pola tumpangsari menyebabkan tanaman tumbuh dengan keadaan ternaungi. Keadaan ternaungani ini dapat meningkatkan produksi etilen, sehingga menimbulkan triple response yang dapat mempengaruhi pertumbuhan dan perkembangan tanaman. Tujuan dari penelitian ini adalah untuk mencari varietas kacang buncis (Phaseolus vulgaris) yang kurang sensitif terhadap peningkatan etilen yang direfleksikan dalam bentuk respon yang minimal terhadap kadar etilen yang tinggi. Metode penelitian yang digunakan yaitu Uji Kertas Digulung dan Diletakkan Dalam Posisi Berdiri Dengan Plastik (UKDdP). Tiga varietas buncis yang digunakan dikecambahkan dengan pemberian perlakuan (pemberian karbid) dan kontrol selama lima hari. Data selisih diperoleh dari kontrol dikurang perlakuan kemudian dianalisis dengan ANAVA one way yang dilanjutkan dengan menggunakan metode BNT 5\% (Beda Nyata Terkecil). Hasil penelitian diperoleh untuk panjang hipokotil tertinggi varietas Horti I $(1,07 \mathrm{~cm})$, diameter hipokotil terbesar varietas Horti II $(0,13 \mathrm{~cm})$, bengkokan epikotil terbesar varietas Lokal $(7,22 \mathrm{~cm})$, panjang sel epidermis terbesar varietas Lokal $(12,17 \mu \mathrm{m})$, dan lebar sel epidermis varietas Horti II $(5,06 \mu \mathrm{m})$. Berdasarkan hasil yang diperoleh, varietas Horti I adalah varietas yang kurang sensitif terhadap peningkatan kadar etilen dibandingkan dengan varietas Horti I dan varietas Lokal.
\end{abstract}

Kata kunci: Triple response, etilen, naungan, kacang buncis, karbid, hipokotil, epikotil, dan sel epidermis 


\section{PENDAHULUAN}

Suku Fabaceae atau polong-polongan merupakan anggota dari bangsa Fabales dengan ciri utama buah berbentuk polong (Simpson, 2010). Suku ini terdistribusi secara luas di seluruh dunia dan memiliki 10.000 jenis yang tercakup dalam 400 marga (Jones dan Luchsinger, 1993). Banyak tumbuhan budidaya penting yang termasuk dalam suku ini salah satunya adalah kacang buncis. Masyarakat Indonesia menjadikan buncis sebagai sayuran karena memiliki kandungan serat yang tinggi.

Produksi buncis di Indonesia menurut Badan Pusat Statistik (2014) pada tahun 2011, 2012, 2013, dan 2014 mengalami fluktuasi secara berturut-turut yaitu, 334.659 ton, 322.145 ton, 327.378 ton, dan 318.214 ton. Kebutuhan masyarakat Indonesia akan buncis dikawatirkan tidak terpenuhi karena produksi buncis yang mengalami fluktuasi (Rahmawati et al., 2017).

Masalah yang umumnya dihadapi dalam membudidayakan tanaman buncis ialah kurangnya lahan untuk bercocok tanam (Kusumiyati et al., 2015). Untuk mengatasi hal tersebut, diperlukan teknik budidaya yang tepat untuk meningkatkan produktivitas lahan, salah satunya budidaya dengan pola tumpangsari. Keuntungan dari pola ini yaitu efisiensi penggunaan air dan lahan, pengurangan populasi gulma, peningkatan pendapatan total pada sistem usaha tani (Rifai et al., 2014), memperkecil erosi, dan menjaga kesuburan tanah (Setiawan, 2009).

Pola tumpangsari buncis pernah
dilakukan dengan tanaman pakcoy
(Mauidzotussyarifah et al., 2018) serta antara cabai merah dan buncis tegak (Karo et al., 2018). Tanaman yang ditanam dengan cara tumpang sari akan mengakibatkan tanaman tumbuh dengan keadaan ternaungi. Keadaan ternaungan ini dapat meningkatkan produksi etilen, sehingga menimbulkan triple response yang dapat mempengaruhi pertumbuhan dan perkembangan tanaman (Walesasi et al., 2016).

Etilen adalah hormon tanaman yang berperan dalam pematangan buah dan mengatur berbegai aspek pertumbuhan tanaman, perkembangan, dan penuaan
(Adams dan Yang, 1979 dalam Bahar et al., 2016). Secara umum tanaman memproduksi etilen dalam jumlah tertentu namun, adanya faktor cekaman lingkungan seperti naungan, kekeringan, kebanjiran, tekanan mekanis, pelukaan, dan infeksi dapat merangsang tanaman untuk menghasilkan etilen secara berlebihan yang menyebabkan pertumbuhan tanaman menjadi terhambat (Ningrum, 2013).

Pada tahun 1901 - 1926, Dimitry Neljubow menunjukkan bahwa etilen dapat mengakibatkan respon rangkap tiga (triple response) pada kecambah kacang kapri. Triple response yang dimaksud adalah menghambat pemanjangan batang, menebalkan batang, dan munculnya kebiasaan membuat lekukan (hook) yang menyebabkan batang tumbuh secara horizontal atau mendatar (Salisbury dan Ross 1995).

\section{METODOLOGI PENELITIAN Bentuk Penelitian}

Penelitian ini menggunakan Rancangan Acak Lengkap (RAL) satu faktor berupa faktor varietas dengan tiga kali pengulangan untuk setiap varietas.

\section{Waktu dan Tempat Penelitian}

Penelitian telah dilakukan pada bulan Januari sampai bulan Maret 2019 di Laboratorium Biologi Dasar dan Laboratorium Ekologi, Jurusan Biologi, Fakultas Matematika dan Ilmu Pengetahuan Alam, Universitas Sam Ratulangi Manado. Sterilisasi alat dan bahan dilakukan di Laboratorium Ekologi, sementara penanaman dan pengamatan dilakukan di Laboratorium Biologi Dasar.

\section{Alat dan Bahan}

a. Alat

Peralatan yang digunakan dalam penelitian ini ialah mikroskop, kaca benda, kaca penutup, optilab, oven, timbangan analitik, magnetic stirrer, busur derajat, jangka sorong, penggaris, kardus, botol air mineral $600 \mathrm{~mL}$, gunting, selotip, pipet tetes, gelas kimia, gelas ukur, erlenmeyer, silet, pinset, kertas label, cool box, alat tulis menulis, dan kamera handphone. 


\section{b. Bahan}

Bahan yang digunakan selama penelitian ini adalah tiga varietas benih kacang buncis (varietas Lokal, varietas Horti I, dan varietas Horti II), karbid, akuades, kertas tissu, kertas merang, dan larutan pemutih komersial.

\section{Prosedur Penelitian \\ Metode Penelitian}

Penelitian ini terdiri dari beberapa tahapan yaitu tahap persiapan, penanaman, desain eksperimen, pengamatan, dan analisis data. Penelitian ini mengikuti prosedur dari penelitian sebelumnya yang dilakukan oleh Wardani et al. (2014) yang dimodifikasi.

\section{Tahap Persiapan}

Pada tahap persiapan, pertama-tama kertas merang $30 \mathrm{~cm}$ x $20 \mathrm{~cm}$ sebanyak 180 lembar disiapkan dan disterilkan dalam oven pada suhu $70^{\circ} \mathrm{C}$ selama 24 jam (Satriadi, 2009). Selanjutnya untuk seleksi benih kacang buncis (Phaseolus vulgaris) dilakukan dengan cara benih diletakkan ke dalam gelas kimia dan direndam dengan menggunakan akuades hingga benih terendam sempurna selama \pm 30 menit. Hal ini dilakukan agar terlihat perbedaan benih yang terapung dan yang tenggelam dengan asumsi bahwa benih yang baik untuk digunakan yaitu benih yang tenggelam. Benih yang telah lulus seleksi, selanjutnya disterilkan selama lima menit dengan menggunakan larutan $\mathrm{NaOCl}$ (pemutih komersial) 2\% dan dibilas sebanyak tiga kali menggunakan akuades (Nio et al., 2010)

Gas etilen yang dipakai dalam penelitian ini dibuat dari 1 gram karbid (kalsium karbida $=C_{a} C_{2}$ ) yang dicampur dengan $100 \mathrm{~mL}$ air (Purnawan, 2010).

Wadah yang digunakan dalam penelitian ini adalah 30 buah botol air mineral

\section{Pengamatan}

Pengamatan penelitian ini dilakukan pada hari ke-lima setelah perlakuan. Panjang dan diameter hipokotil diukur menggunakan

berukuran $600 \mathrm{~mL}$ yang sudah dipotong bagian atasnya.

\section{Penanaman}

Penanaman kacang buncis mengikuti metode Uji Kertas Digulung dan Diletakkan Dalam Posisi Berdiri Dengan Plastik (UKDdP) dengan media merang (Kartasapoerta, 1992). Dua buah kertas merang yang sudah disterilkan diletakkan di atas plastik (wrap plastic), selanjutnya kertas merang dibasahi dengan air secukupnya. Sebanyak 25 benih kacang buncis diatur sedemikian rupa di atas kertas merang kemudian selembar kertas merang yang sudah dibasahi dengan air secukupnya diletakkan pada salah satu sisi benih sebagai penutup yang kemudian digulung beserta alasnya. Setelah itu, dalam posisi tegak kertas merang diletakkan di dalam botol yang telah diberi air sebanyak $20 \mathrm{~mL}$.

\section{Desain Eksperimen}

Penelitian ini menggunakan tiga varietas buncis yaitu varietas Lokal (VL), varietas Horti I (VHI), dan varietas Horti II (VHII). Dua buah kardus yang digunakan sebagai ruang tertutup, masing-masing menampung 15 botol yang berisikan benih kacang buncis. Pada kardus pertama diberi label kontrol tidak diberikan perlakuan karbid (KK) dan pada kardus yang kedua diberikan label perlakuan karena terdapat perlakuan karbid (KP) yang diberikan pada hari pertama penanaman.

Tabel 1. Desain eksperimen penelitian

\begin{tabular}{ccc|ccc}
\hline \multicolumn{3}{c|}{$\begin{array}{c}\text { Kardus Pertama } \\
\text { (Kontrol) }\end{array}$} & \multicolumn{3}{c}{$\begin{array}{c}\text { Kardus Kedua } \\
\text { (Perlakuan) }\end{array}$} \\
\hline$K_{K} V_{L}$ & $K_{K} V_{H I}$ & $K_{K} V_{H I I}$ & $K_{P} V_{L}$ & $K_{P} V_{H I}$ & $K_{P} V_{H I I}$ \\
$U_{1}$ & $U_{1}$ & $U_{1}$ & $U_{1}$ & $U_{1}$ & $U_{1}$ \\
$K_{K} V_{L}$ & $K_{K} V_{H I}$ & $K_{K} V_{H I I}$ & $K_{P} V_{L}$ & $K_{P} V_{H I}$ & $K_{P} V_{H I I}$ \\
$U_{2}$ & $U_{2}$ & $U_{2}$ & $U_{2}$ & $U_{2}$ & $U_{2}$ \\
$K_{K} V_{L}$ & $K_{K} V_{H I}$ & $K_{K} V_{H I I}$ & $K_{P} V_{L}$ & $K_{P} V_{H I}$ & $K_{P} V_{H I I}$ \\
$U_{3}$ & $U_{3}$ & $U_{3}$ & $U_{3}$ & $U_{3}$ & $U_{3}$ \\
\hline \multicolumn{3}{c}{ jangka sorong, sedangkan bengkokan (hook) } \\
epikotil diukur menggunakan busur derajat.
\end{tabular}




\section{Analisis Data}

Data penelitian yang diperoleh kemudian dianalisis dengan menggunakan analisis varian (ANAVA) one way dengan uji lanjut BNT 5\%.

\section{HASIL DAN PEMBAHASAN}

Nilai selisih dalam penelitian ini diperoleh dari nilai kontrol dikurangi nilai perlakuan. Hal ini bertujuan untuk melihat pengaruh pemberian karbid terhadap kecambah buncis, sehingga data yang dianalisis adalah data hasil selisih.

Berdasarkan perhitungan rata-rata selisih panjang hipokotil tiga varietas, diperoleh hasil varietas Lokal $-0,45 \mathrm{~cm}$, varietas Horti I $1,07 \mathrm{~cm}$, dan varietas Horti II $-0,67 \mathrm{~cm}$ (Gambar 1). Pada hasil perhitungan selisih, dapat diasumsikan bahwa varietas Horti I merupakan varietas yang kurang sensitif terhadap pemberian etilen yang ditunjukkan dengan nilai selish rata-rata panjang hipokotil yang terpanjang dibandingkan dengan varietas Lokal dan varietas Horti I. Hasil uji sidik ragam juga menunjukkan adanya perbedaan yang nyata antara ketiga varietas buncis. Hal ini dapat dilihat dari nilai signifikansi panjang hipokotil yang kurang dari 0,05 sehingga perlu dilakukan uji lanjut BNT 5\%. Hasil uji lanjut BNT 5\% menunjukkan varietas Horti I dan varietas Lokal berbeda signifikan.

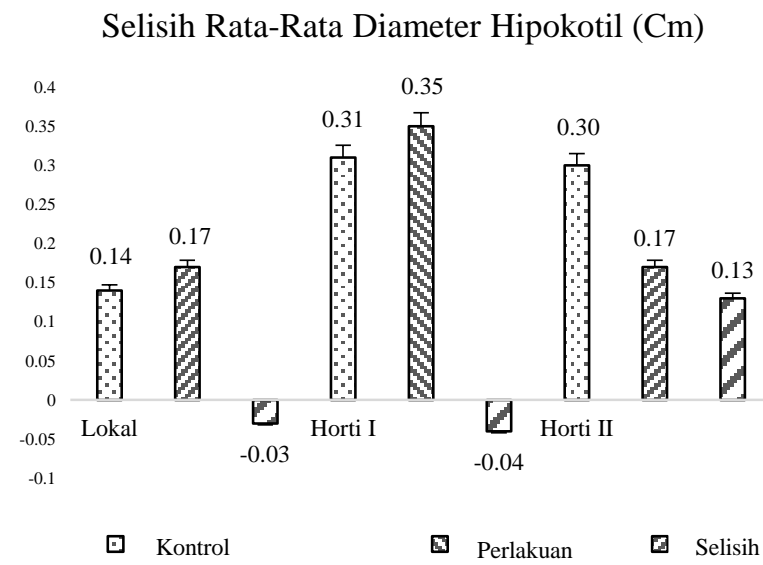

Gambar 1. Selisih Rata-Rata Panjang Hipokotil varietas Lokal, Horti I, dan Horti II.
Kecambah yang menunjukkan triple response ditandai dengan pertumbuhan panjang hipokotil yang terhambat dan pada bagian batangnya terjadi penebalan. Penebalan yang terjadi dikarenakan sel yang mengalami pemelaran kearah samping sehingga pertumbuhan batang lebih pendek dan tebal (Salisbury dan Ross, 1995). Pemelaran yang terjadi dikarenakan oleh adanya tekanan turgor pada dinding sel yang mengakibatkan sel mengalami keadaan turgid (Salisbury dan Ross, 1995).

Hasil perhitungan selisih rata-rata diameter hipokotil dari ketiga varietas buncis yaitu pada varietas Horti II $0,13 \mathrm{~cm}$, varietas Horti I $-0,04 \mathrm{~cm}$, varietas Lokal $-0,03 \mathrm{~cm}$ (Gambar 2). Selisih tertinggi terdapat pada varietas Horti II sehingga varietas Horti II dapat dikatakan sebagai varietas yang memperlihatkan respon yang kurang sensitif terhadap etilen. Hal ini dapat dilihat dari nilai selisih diameter hipokotil yang paling besar. Di sisi lain, varietas Lokal dan varietas Horti I memiliki respon sensitif terhadap pemberian etilen dengan nilai selisih terkecil. Selisih yang bernilai negatif tersebut menunjukkan bahwa diameter hipokotil varietas yang dikecambahkan pada perlakuan pemberian karbit lebih besar dibandingkan dengan kecambah kontrol, sehingga merefleksikan respon yang positif terhadap keberadaan etilen.

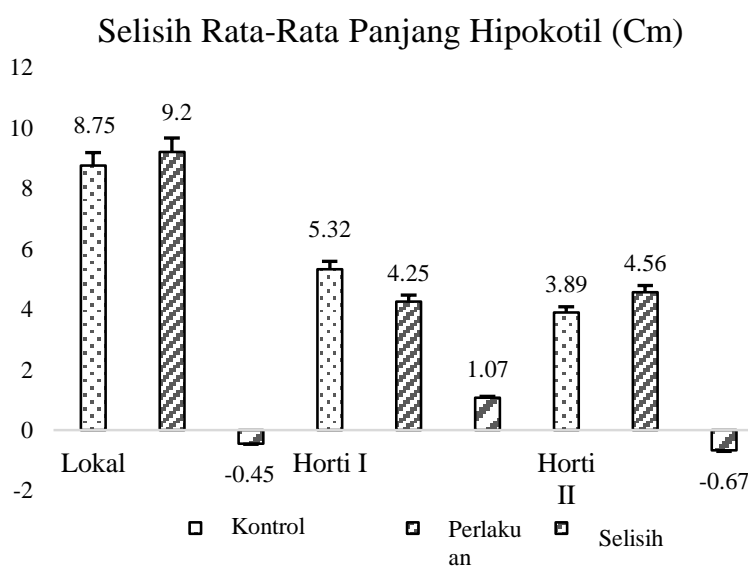

Gambar 2. Selisih Rata-Rata Diameter Hipokotil varietas Lokal, Horti I, dan Horti II. 
Hasil uji sidik ragam memperlihatkan tidak terdapat perbedaan yang signifikan antara ketiga varietas buncis sehingga tidak dilakukan uji lanjut BNT 5\%. Hal ini dikarenakan keluarnya sebagian air dari dalam sel yang menyebabkan tekanan turgor sel epidermis mengalami penurunan sehingga terbentuknya jarak antara dinding sel dan membran. Hal ini yang mengakibatkan bentuk sel epidermis memanjang (Salisbury dan Ross, 1992).

Epikotil adalah bagian dari axis atau pucuk kecambah yang terdapat sel meristem apeks maupun adventif pada jaringan meristematis, sebagai pusat tumbuh tanaman untuk mengatur pertumbuhan (Slamet et al., 2011). Menurut Dimitry N. Nelbow, pertumbuhan tanaman dapat terganggu disebabkan karena bengkokan pada epikotil yang dapat memungkinkan batang bertumbuh secara horizontal atau mendatar (Salisbury dan Ross, 1995).

Gambar 3 memperlihatkan hasil perhitungan selisih rata-rata ketiga varietas buncis tertinggi adalah varietas Horti II 3,91 $\mathrm{cm}$, varietas Lokal 7,22 cm, dan varietas Horti I -7,22 cm dengan derajat bengkokan epikotil terbesar ialah varietas Horti II. Hal ini dapat dilihat dari nilai selisih rata-rata terbesar yang menandakan bahwa varietas Horti II merupakan varietas yang tahan terhadap etilen, sedangkan varietas Lokal dan varietas Horti I memperlihatkan respon positif terhadap keberadaan etilen, sehingga nilai derajat bengkokan epikotil menunjukkan nilai paling kecil. Namun, hasil analisis dengan ANAVA pada taraf kepercayaan 95\%, memperlihatkan bengkokan ketiga varietas kecambah buncis tidak berbeda nyata sehingga uji lanjut BNT 5\% tidak dilakukan.

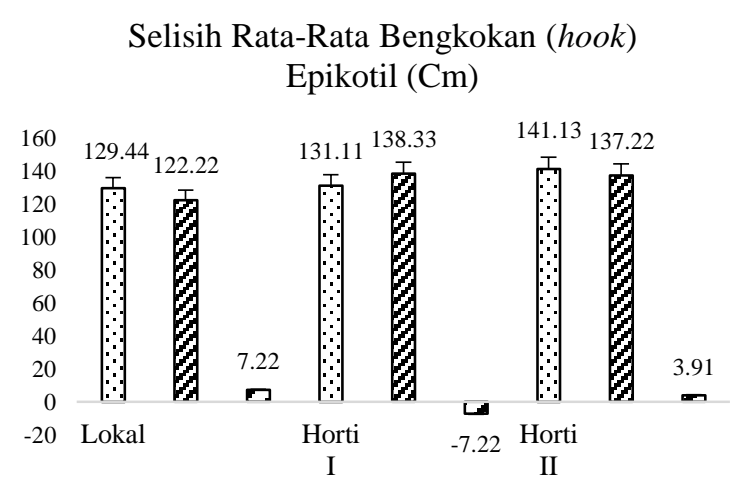

Gambar 3. Selisih Rata-Rata Bengkokan Epikotil varietas Lokal, Horti I, dan Horti II.

\section{KESIMPULAN}

Berdasarkan hasil penelitian dapat disimpulkan bahwa varietas Horti I adalah varietas yang kurang sensitif terhadap pemberian etilen yang direfleksikan dengan panjang hipokotil tertinggi.

\section{SARAN}

Perlu dilakukan penelitian lebih lanjut untuk melihat pada tingkatan konsentrasi etilen yang mampu menunjukkan triple response kacang buncis (Phaseolus vulgaris).

\section{DAFTAR PUSTAKA}

Badan Pusat Statistik. 2015. Data Produktivitas Buncis di Indonesia. http://www.bps.go.id/index.php/pe ncarian?keywordforsearching= luas+panen+buncis\&yt.[28 Oktober 2018].

Bahar, E., A. M. Yusoff, dan A. Rasyad. 2016. Pengaruh Etilen Terhadap Daun Pada Empat Varietas Cabai (Capsicum annuum L.) Di Lingkungan dan Kondisi Iklim Kabupaten Rokanhulu. Jurnal Sungkai 4(2): 73-78.

Jones, S. B., Jr. A. E. Luchsinger. 1993. Plant Systematics, Second Edition.

Karo, B. B., A. E. Marpaung, D. Masaddad. 2018. Sistem Tanam Tumpang Sari Cabai Merah dengan Kentang, Bawang Merah, dan Buncis Tegak. J. Hort. 28(2): 219-228.

Kartasapoerta, A. G. 1992. Teknologi Benih: Pengolahan Benih dan Tuntunan Praktikum. Rineka Cipta, Jakarta.

Kusumiyati, W., N. Sutari, dan Raniska. 2015. Respons Pertumbuhan Hasil, dan Kualitas Hasil Buncis Tegak terhadap Pemberian berbagai Dosis Kompos dan Interval Panen pada 
PHARMACON- PROGRAM STUDI FARMASI, FMIPA, UNIVERSITAS SAM RATULANGI, Volume 8 Nomor 3 Agustus 2019

Inceptisols Jatinangor. Jurnal Kultivasi 14(2): 92-98.

Mauidzotussyarifah., N. Aini, dan N. Herlina. 2018. Optimalisasi Pemanfaatan Lahan dengan Pola Tanam Tumpangsari pada Tanaman Buncis (Phaseolus vulgaris L.) dan Tanaman Pakcoy (Brassica rapachinensis L.). Jurnal Produksi Tanaman 6(2): 246-251.

Ningrum, D. A. 2013. Pengaruh Lama Waktu Pemeraman Pisang Raja Bulu (Musa paradisiaca L. Var Sapientrum) Menggunakan (Batu Karbid) terhadap Kadar Karbohidrat dan Vitamin C. IKIP PGRI, Semarang.

Nio, S. A., S. M. Tondais, dan R. Butarbutar. 2010. Evaluasi Indikator Toleransi Cekaman Kekeringan pada Fase Perkecambahan Padi (Oryza sativa L.). Jurnal Biologi 14 (1): 5051.Rifai, A. S., Basuki, dan B. Utomo. 2014. Nilai Kesetaraan Lahan Budidaya Tumpangsari Tanaman Tebuh dan Kedelai: Studi Kasus di Desa Karangharjo Kecaman Sulang Kabupaten Rembang. Jurnal Widyariset 17(1): 59-70.

Purnawan, H. 2010. Pengertian Karbid. Universitas Gajah Mada.http://harispurnawan.web.ug m.ac.id/?pilih=news\&mod=yes\&ak si=lihat\&id=2. $\quad[10 \quad$ November 2018].
Salisbury, F.B, dan C. W. Ross. 1995. Fisiologi tumbuhan Jilid 3 Edisi ke4. ITB. Bandung.

Satriadi, M. 2009. Validasi Metode Uji Daya Berkecambah Benih Trembesi (Samanea Saman) Menggunakan Instruksi Kerja 08. Badan Perbenihan Tanaman Hutan, Bali.

Setiawan, E. 2009. Kearifal lokal Pola tanam Tumpang Sari di Jawa Timur. Jurnal Agrovigor 2(2): 79-89.

Simson, M. G. 2010. Plant systematics. Elsevier Academic Press, California.

Slamet., J. Saptowo, M. Pardal, Herman, dan Wartono. 2011. Regenerasi Kedelai melalui Kultur Epikotil dan Teknik Aklimatisasi. Jurnal Penelitian Pertanian Tanaman Pangan 30(1): 38-42.

Wardani, K. E., F. R. Mantiri, A. S. Nio, dan M. J. Rumondor. 2014. Kajian Ethylene Triple Response terhadap Kecambah Tiga Varietas Kacang Kedelai. Jurnal Bioslogos 4(2): 7682.

Walesasi, K., F. R. Mantiri, H. Simbala, dan M. Rumondor. 2016. Kajian Ethylene Triple Response terhadap Kecambah Tiga Varietas Kacang Hijau. Jurnal Ilmiah Sains 16(2): 73-79 